\title{
Developing Students' English Skill Through Digital Video as Multimodal for Young Learners in Online Learning
}

\author{
Arik Susanti ${ }^{1, *}$ Careninda Presdyasmara ${ }^{1}$ Fadilla Dewi ${ }^{2}$ Yunita Wardani $^{3}$ \\ 1, 2, 3 English Department, Faculty of Language and Art, State University of Surabaya, Indonesia \\ *Corresponding author.Email: ariksusanti@unesa.ac.id
}

\begin{abstract}
This study described EFL young learners how to develop their English using digital video as multimodal in online learning. Recently, all the processes of teaching-learning have been conducted in online learning mode. Therefore, technology has an important role to motivate students, especially young learners, to learn and improve their English skills. Using digital video can help learners to both interpreting and producing multimodal texts. It can also develop young learners for making meaning since they can watch something displayed in video using English. Digital video provides learners with imagery and audio-visual modes of representation beyond the linguistics mode for engaging young learners to learn English. The participants are twenty-four students in primary school conducting online learning in a primary school of Muhammadiyah 24 Surabaya. The instruments were observation sheet and rubric to analyze students' multimodal composition. The results showed that by using digital video, the students could be able to write simple story and present their story. Although, they made mistakes in grammatical aspects, they could write comprehend story. It could be suggested that multimodal could be used in teaching and learning process to engage students' motivation and competence.
\end{abstract}

Keywords: Digital, Video, Multimodality, Design, Literacy, Competence.

\section{INTRODUCTION}

Recently, the increase of technologies has developed how EFL learners learned English skills [1]. For example, to improve their writing ability, L2 learners can use blogging, fan fiction writing, or genre construction in specific online newsgroup discussions and many others. Moreover, the existence of Corona Virus 2019 (Covid19) has profoundly altered all aspects of life, including educational field that has fostered the use of technologies in education. One of the regulations that must be implemented is homeschooling for students ranging from the early childhood education level to higher education (Regulation of Indonesian Government No.21, 2020). It means that distance learning or online systems have provided a solution for schools or universities to start implementing a school from home (SFH) system. Online learning emphasizes Internet-based courses offered synchronously and asynchronously [2].

The existence of technology has powerful tools to help EFL learners to understand English skills and participate in multimodal literacy practices. Lai, Yeung, and $\mathrm{Hu}$ [3] also declare that the use of technological resources outside the classroom activities could foster learner autonomy such as Facebook, Twitter, Google, YouTube, Google Classroom can help learners communicate with others and become proactive and independent in learning [4]. The students are relatively easy to learn English using digital technology since the learners are digital natives who need to be skillful in both interpreting and producing multimodal text [5]. They easily get information or written text from web or digital media sources that are full of images that help them understand the concept easily. The use of technology makes them enjoy learning a language since they can explore many kinds of knowledge or information in the form of attractive images or audio-visual rather than written elements. In the digital era, young learners prefer to learn something based on the picture or image, or video rather than text. Therefore, the teacher must implement multimodal pedagogical practices during online learning that helps learners understand literacy concept since literacy should be multimodal because the process of communication is delivered through integrated 
composition both written and audiovisual. A variety of texts associated with information and multimedia technologies are incorporated into literacy for the multimodal meaning-making representation.

To promote students' English competence both spoken and written skills in online learning, digital video can be implemented. Digital video combines various multimedia sources such as images, audio, and videos [6]. It is a good example of promoting students' speaking and writing skills and providing them with experiential in learning [7]. All learning activities are focused on developing students' knowledge, attitude, collaboration, and multiliteracy skills. The teacher implements studentcentered activities by providing many activities that ask them to construct knowledge or information independently or in teamwork. There is a change in teacher attitudes from past experience to online learning. In the past, the teacher dominated the class and always delivered materials that made students be passive learners since they always listened and did what their teacher said. Today, the condition is different since the use of technology helps teachers to use many kinds of multimedia resources that help them to motivate learners to develop English skills both written and oral aspects. Consequently, the students are interested to learn English.

Using digital video, young learners develop their spoken or written English skills because they can watch something displayed in video using English. They easily understand making meaning from the story. They have started to draw on multimodal approaches to composition because digital video changes one's way of making expressing meaning. Digital video or digital multimedia provide learners with imagery and audio-visual modes of representation beyond the linguistics mode for engaging young learners to learn English. Although young learners only watch a sign, a picture, or few words displayed in the video, they can attract them to read and listen since they are full of color images. It can also reveal deep meaning for them. They can convey meaning within certain subject areas more powerfully than the linguistic mode. By learning English using digital video, the learners would enjoy studying since they have learned English as if they are in the real world. They will write a story in the form of a video and then is uploaded it to the class group or their Instagram. The learners become active participants in the process of online learning.

Some empirical studies have shown that digital storytelling can be used to improve students writing composition through modality. Yang investigates that the development of multimodal digital storytelling can guide university students to write narrative texts and develop students' understanding of multimodal designers' thinking process in constructing their digital stories [8]. Moreover, thirty digital storytelling constructed narrative texts could help readers explain and interpret the story's meaning since images play a significant role as evaluation. Moreover, culturally specific elements in digital narratives interact with a global perspective for a universal audience [9]. Next, World Wide Web could improve students' argumentative essay writing ability at the university level. The results showed that multimodal composition consisted of linguistic mode (worddominated discourse) and non-linguistic modes used to illustrate written essays to express their emotional connection with the topic and national identities.

However, researches about the benefits of technology or digital storytelling to develop English based on multimodality has been scant so the present study attempts to fill this gap by investigating how digital video develops digital literacy and writing ability for young learners in online learning mode. In this study, young learners have learned English using digital video to explore their English skills and understand makingmeaning during online learning mode. It is known that multimodality provides image, visual, audio, and spatial modes of representation that help young learners learn English by forming integrated multimodal texts and improving written and oral skills in and beyond the classroom [10]. Thus, the study aims to describe EFL young learners develop their writing skill using digital video in online learning. The learners can easily learn English since the implementation of multimodality in online learning provides them with many pictures, images, and audio-visual that help them understand English skills and make meaning. It also makes them enjoy learning English since they can construct their knowledge and information by themselves. As a result, they can improve their English skills during online learning and help them to be independent learners. Therefore, the research question of this study is "How do EFL young learners develop their English skills using digital video as multimodal during online learning?"

\subsection{Multimodality Approach}

According to multimodality approaches to communication, meaning-making methods require cultural ways of using forms of representation available in a given instance of communication [11]. Multimodality refers to the way people behave by using gestures or vocabulary that is articulated or portrayed in a variety of media. It means that multimodality refers to the use of different sensory modalities to obtain information, such as tactile, visual, and auditory. As a result, multimodality has been described as an approach to representation and communication that relies on a variety of modes that have all been socially established as tools for making-sense. Societies have developed modes such as gesture, sound, image, color, or layout as a set of organized resources. Kweldju supports that multimodality focuses on verbal and visual aspects of 
texts so that multimodality does not only consider contents but also aesthetics [12]. Contents include writing and image with their color, fonts, shapes, and layout while aesthetics are similar to style, symbolism, and fashion.

In the English language learning context, multimodality plays a crucial role in the development and delivery of materials. Multimodal environments allow English language learners to create and communicate with particular contexts of language use. Learners must be aware of the linguistic elements when developing appropriate contexts of language use and complement these with their specialized content [13]. In addition, based on the constructivist view of learning, learners should be offered opportunities to engage in learning processes by doing. It can be conducted by engaging learners to design multimodal artifacts with greater flexibility and creativity in their content-specific learning [14]. Thus, Multimodality engages learners in a complex process of sense-making [15] based on the social interactions between language and the other semiotic systems represented.

Kress [16] proposed multimodal approach that emphasizes the sign-maker and their situated use of modal resources. The framework of multimodal interactional analysis is used to understand the mediated relationship between multimodal sign users and their sociocultural habitus. To implement a multimodal approach of design, English language learners are considered active agents who approach the design of their digital stories with communicative interest and intent. Their process of developing multimodal digital stories guides their logic of multimodal digital story design, such as semiotic resources, and employs them in their digital video. Therefore, the design concept is particularly useful to understand how learners engage in multimodal composing and communication as active learners. The design concept is used as a primary framework to make sense of how English language learners approach the multimodal composing of digital video in this study that motivates learners' interest to communicate in a certain context. It can also serve learners to understand their logic and ensemble act of multimodal resources.

Godhe and Magnusson define multimodal design as situated social sign-making processes to utilize learners with multimodal semiotic resources in their repertoire to create and deliver their message based on their interpretation of the texts [13]. The notion of design encourages learners to be innovative and creative in human communication. Learners are encouraged to serve as active designers, shaping and reshaping ways of presenting messages by utilizing and mingling semiotic resources for their potential, focusing on the meanings to be delivered.

In the process of design, Kress [16] said that the essential aspects in making the students active during the learning process in multimodality are transformation and transduction. In transformation activities, students take actions to reorganize and rearrange elements (semiotic resources) within a mode to generate new meanings: for example, transforming the size, color, or position of an image. In this case, only the grammar, organization, logic, etc., within the mode (e.g. written texts) are reconstructed. However, in transduction process of activities, students can reshape semiotic resources or tools through styles, moving from one mode to another to convey the intended meaning (e.g., presenting an inner idea in the form of spoken language; changing the presentation of spoken language into the form of video). Since the different mode which has different properties for the act of message transmission, the logic of presentation may no longer be the same. For example, the mode of expression performs in the properties of pitches, tones, and stress, while the mode of picture performs in the properties of position, line, and color.

Learners must arrange and orchestrate semiotic resources in multimodal forms when they design with multimodal resources. They can use these multimodal forms or modes that include more than language; images, animations, music, gestures, speech, writing, to name a few when they can employ for their design [15]. As a result, multimodal semiotic resources may require learners to perform the activities based on a new logic.

Learners need semiotic resources when they are designing with multimodal forms. Semiotic resources are materials that have been historically and culturally constructed such as artifacts, objects, signs, and concepts [16]. Learners can create descriptions or interpretation of semiotics tools based on their sociocultural personal or group experience. These interpretations can help them establish and create new meanings for the semiotic resources in a different communicative context, such as in a multimodal design.

It is important to note that the effective use of semiotic tools in multimodal design requires cultural affordance or creating writing in digital video. Learners should make connection between themselves and the semiotic tools and objects or opportunities provided to them in their communicative competence. Semiotic tools and objects can help learners to recognize meaning and value. Finally, learners can use them in their social and cultural activities.

\subsection{Digital Video}

Digital video combines various multimedia sources such as images, audio, and videos [6]. It is a good example to promote students' speaking skills and provide them with the value of experiential learning [7]. Video digital projects offer a movement in a learning environment that can support language learning, reduce anxiety, and boost students' enthusiasm for learning [17]. Video digital also 
facilitates students to understand the text from the pictures (semiotic resources), modes of communication, and semiotic relationship. Another researcher also says that digital video storytelling could improve students' oral performance and motivation for pre-intermediate level in Iran [18]. To sum up, it is said that video production is a potential learning tool, which will be very beneficial for the students when implemented appropriately. It will improve students' language skills and their ability to work in a team, boost their motivation to learn, enable them to explore their knowledge.

\section{METHODS}

This research design was qualitative method since the purpose of the study was to describe how to develop students' English skills through digital video as multimodality perspective in online education. There were 24 participants in fifth grade in one of private primary school in Surabaya. It was known that during the Covid-19 outbreak, this school has been implementing online learning to achieve the goal of learning English. It is hoped that students can acquire knowledge and skills by using technologies in learning English. The increase of technologies has developed ESL learners' English skills, such as digital video to improve listening, speaking or writing skills. Moreover, the learners had abundant experiences using technologies and participating in online learning. To develop the students' English skills, digital video can guide students to understand materials. It consists multimodal literacy resources that help young learners to communicate their English as a foreign language. Students have exposed some examples of digital stories and multimodal resources.

The research instrument was observation sheet to describe the process of development English skills for young learners that contains several aspects of multimodal texts with the following characteristics:

(1) The transformation consists of some elements such as size, color, words, pictures, image, organization, syntax, and logic.

(2) The aspects of English skills consist of abilities in reading, writing, speaking, and listening, the ability to locate, evaluate, and use information, the ability of questioning, analyzing, interpreting, evaluating and creating media messages, managing and consuming tools.

All the aspects or elements that are used in the observation sheet adapted from Kress [16].

All the data would be collected and examined through coding based on the classification of observation sheets that have been designed. Some steps that they do in the coding process. The interactions will be coded according to transformation and aspects of English skills.

\section{RESULTS AND DISCUSSION}

To develop young learners' English skills using digital video as multimodal during online learning, there were some steps that must be done in teaching English for young learners.

First, the teacher taught students in synchronous mode, using zoom meeting. The teacher distributed the link to his students the day before. In zoom meeting the teacher taught students using pictures to motivate students to be ready in joining the process of teaching and learning.

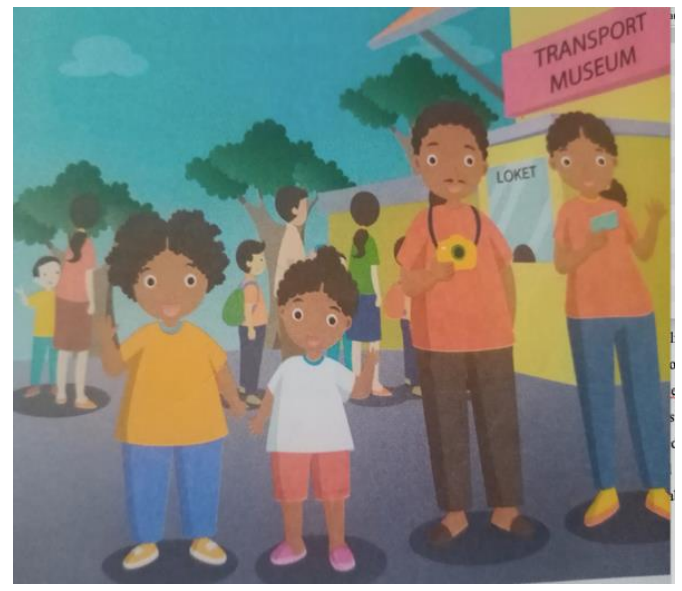

Figure 1 Picture to motivate students

At that time the materials were about their holiday. The teacher motivated them by asking them such questions "Where did you go when you were in holiday? Some of students answered that they were going to Pacet, Malang, Bandung and others. How did you feel when you were a holiday? Some students answered fun, bored, or tiring and many others. With whom did you go there? Some students answered with my family, my relatives or my friends.

When the students were ready to join in the learning process, the teacher provided several pictures completed by phrases or sentences and asked them to repeat the phrases. The teacher also provided a video and asked them to watch that video and repeat it. It was used that they are able to pronounce them well. The teacher also asked some students to demonstrate how to pronounce that phrases or sentences. It is known that time of teaching in synchronous modes was limited, then the teacher continued in asynchronous mode, such as WhatsApp Group (WAG).

In WhatsApp Group, the teacher uploaded English materials in video and asked students to repeat words and answer the questions based on the materials. All the students did many activities to achieve their goal, that is, they can communicate using English in the simple conversation or write a simple story. The English materials used were in the form of multimodal design. The students could learn English without their teacher's 
presence because all the materials were video and completed by pictures.

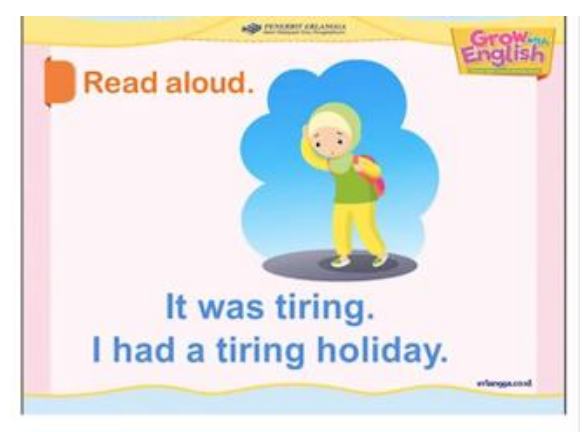

Figure 2 Reading aloud

The first material, the students watched a video and read aloud. In this activity, the students listened and repeated until they could pronounce well. The parents would guide and accompany them. In this opportunity, the students learned how to pronounce certain text. They also learned how to practice transactional text based on the video that they heard. If the students could do well, they did exercises by matching the pictures and sentences, choosing the best pictures and answering the questions based on audio that they have listened.

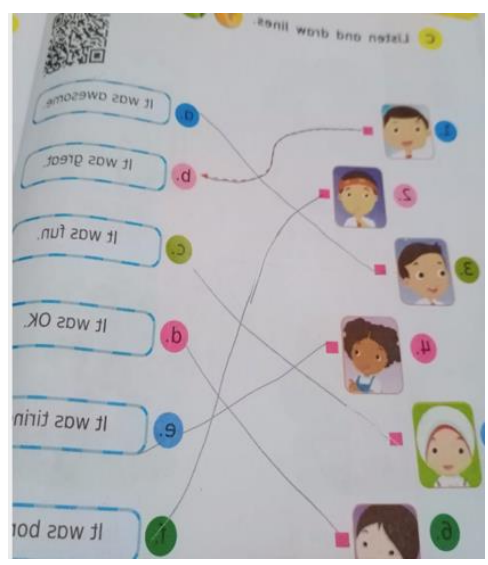

Figure 3 Matching

In this stage, students practiced how to guess the meanings/phrases based on the pictures and video that they had watched. In this case, the students practiced how to match either sentences or phrases into the pictures. Here, the students could check their answers based on the answer key distributed by their teacher. Parents' roles are required to guide students when they were learning English. When the students passed these exercises, they could continue with the next materials.

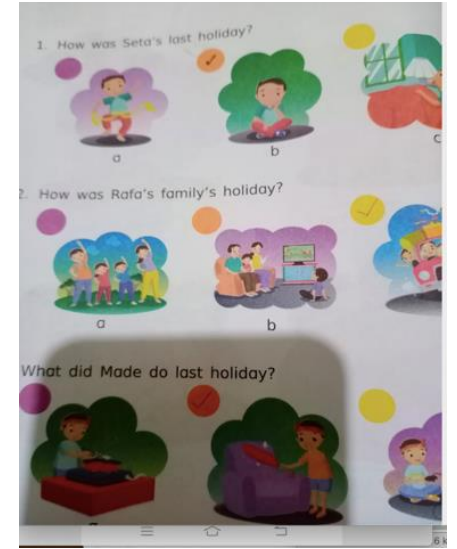

Figure 4 Listening and matching

In this part, the students watched a video consisted several statements from video and chose the best picture based on their recording. The students did that task enjoyable since the materials were given in colorful pictures.

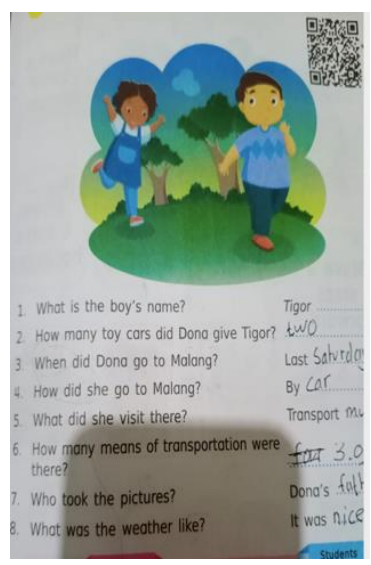

Figure 5 Listening comprehension

After that, the students would watch a short story and answer questions based on their video. The students have learned how to comprehend the story based on the video. Most of the students could answer the question and the environment was in good condition. The students showed that they were happy to study English since all their materials are attractive to increase their motivation. If all the students have understood the materials, they could write a simple story based on their experience.

The final step was writing and speaking. In this opportunity, the students could write a simple story based on their experiences during the holiday. To help students to write a story, the teacher recommended students to use pictures. It could help them to imagine their story. It also helps them write simple sentences about their holiday. Using pictures also helps them to write a chronological story. Figure 6 are the samples of students' composition. 


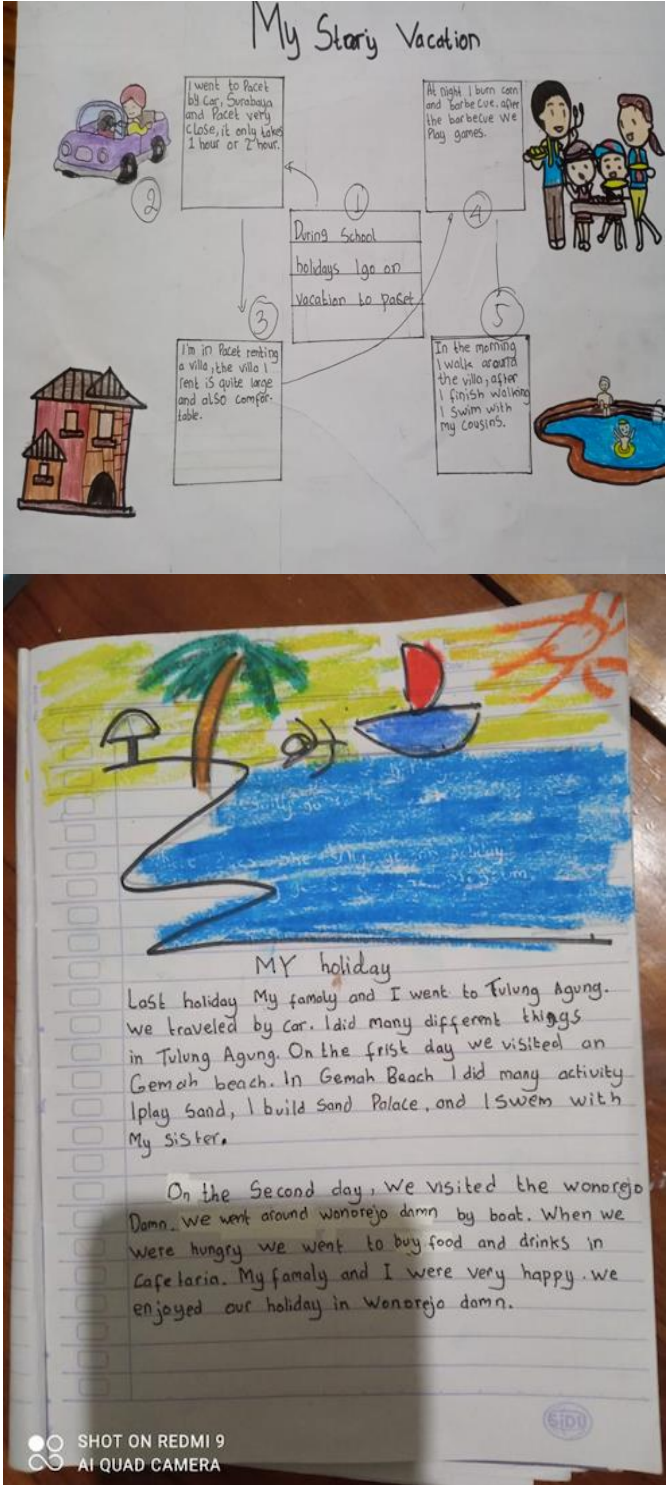

Figure 6 Students' composition

Based on the students' composition, the result showed that the students could write their story well. It could be seen in the Table 1 .

Table 1. Aspects of students' composition

\begin{tabular}{|c|c|c|}
\hline No & Elements & Explanation \\
\hline 1 & Size & Average \\
\hline 2 & Color & Good \\
\hline 3 & Pictures & Good \\
\hline 4 & Grammar & Average \\
\hline 5 & Organization & Good \\
\hline 6 & Logic & Good \\
\hline
\end{tabular}

Table 1 describes that the students' color, pictures, organization, and logic were good. It means that the use of picture and color helped them to organize their story well. They were able to mention their character, such as my family and I. They could also mention the setting of place, namely Pacet, Surabaya, Gemah beach, Wonoroje Lake, and villa and time setting; for example, holiday, in the morning, at night, last holiday, on the first day and the second day. Moreover, the students could write the events chronologically. It showed that pictures helped them to organize and imagine their story. Although the pictures in the first story were not arranged in good order, the use of number and arrow helped readers read the story. It also showed that the students' logic are good.

However, they made several mistakes in grammar namely, there was no verb Surabaya and Pacet very close. Moreover, the students were not aware the use of tense. Most of them still used present simple tense, such as 'we play games,' 'I walk,' 'I finish,' and 'I swim'. They also missed the use of punctuation, such as coma or full stop. Fortunately, they could comprehend their story well. After the learners had written the story, they spoke it using a voice note and sent it to WhatsApp group because the students did not feel confident recording in the video. They felt anxious and nervous when they were asked to speak in English. To sum up, the use of pictures and color help learners write a composition. They started to write a topic, them they decided the place, with whom they went, their accommodation and their activities when they were on holiday.

The use of technology such as digital video in the learning process has been proven to help students be more active during the teaching and learning process as well as improve their writing and speaking skills. Digital video combines various multimedia sources such as images, audio, and videos [6]. It is a good example to promote students' speaking and writing skills and provide them the value of experiential in learning [17]. Through digital video including semiotic resources that are attractive, eye-catching, and based on real-life situation could also help to increase students' awareness since it allows them to learn with audiovisual and eventually lead them to practice their skills in real life.

The materials presented in form of a digital video also motivate students to explore their creativity and imagination. As a result, when students are asked to conduct the digital project, their motivation, collaboration, and critical thinking can be enhanced. Using verbal and visual elements such as signs and symbols in digital video is the key to enhancing classroom literacy and linguistic activities. All learning activities are focused on developing students' knowledge, attitude, collaboration, and multiliteracy skills.

The implementation of student-centered activities by providing many activities that ask them to construct knowledge or information by themselves supports online 
learning to be much more meaningful; as mentioned earlier, students' creativity to use English as language text by using images or videos as visual text to work on their projects and task outcome is significantly promoted. The students taking a role in reorganizing and rearranging semiotics elements to generate new meanings is essential in making the students active during the online learning process in multimodality as stated by Kress [16]. The transforming of the size, color, or position of an image could help students learn grammar, organization or logic. They could reconstruct in written text.

Furthermore, digital video could also promote their English skills. The learners practice how to read, write, speak, and listen to the materials in the target language. They are able to use information, analyze, interpret, evaluate and create story using media messages. It is in line with Kress [16] that learners need semiotic resources when they are designing with multimodal forms to construct their writing. It is said that the use of digital video is an effective way to help students to foster their English skills. Learners could make connection between themselves and the semiotic tools and objects or opportunities provided to them in their communicative competence. Therefore, semiotic tools and objects can help learners to recognize meaning and value. Finally, learners can use them in their social and cultural activities.

\section{CONCLUSION}

This study presented that utilizing digital video during the teaching and learning process could develop students' English skills. Therefore, the creative teacher must be required to make the students engage in online learning. The materials that are going to be delivered to learners must be well prepared and clear so that they are able to follow all the instruction given and the learning objectives could be achieved optimally. The use of digital video could also motivate the learners to study English since it facilitates students to understand the text from the pictures (semiotic resources), modes of communication, and semiotic relationship. It is also a potential learning tool to improve students' language skills and their ability to work in a team to foster their collaboration skills, boost their motivation to learn, as well as enable them to explore their knowledge. It is also recommended for English teachers to use digital video to teach English in other subject.

\section{AUTHORS' CONTRIBUTIONS}

All authors involved in this study conceived the research that has been designed. The experiments are conducted by Arik Susanti as well the data that have been analyzed. All authors played a role in the manuscript revision including editing and review before submission. All authors also approved the latest version that was decided to be the final manuscript.

\section{ACKNOWLEDGMENTS}

We would like to say thank you to Mrs. Pratiwi as the head of English Department that always motivates us to participate in an academic forum.

\section{REFERENCES}

[1] M.M. Grant and R.M. Branch, "Project-Based Learning In a Middle School: Tracing Abilities Through The Artifacts of Learning," Journal of Research on Technology in Education, vol. 38, no. 1, pp. 65-98, 2005.

[2] C.G. Ogbonna, N.E. Ibezim, and C.A. Obi, "Synchronous versus asynchronous e-learning in teaching word processing: An experimental approach," South African J. Educ., vol. 39, no. 2, pp. 1-15, 2019. DOI: 10.15700/saje.v39n2a1383

[3] C. Lai, Y. Yeung, and J. Hu, "University student and teacher perceptions of teacher roles in promoting autonomous language learning with technology outside the classroom," Comput. Assist. Lang. Learn., vol. 29, no. 4, pp. 703-723, 2015. DOI: $10.1080 / 09588221.2015 .1016441$

[4] T.Q. Tran and T.M. Duong, "EFL learners' perceptions of factors influencing learner autonomy development," Kasetsart J. Soc. Sci., 2018. DOI: 10.1016/j.kjss.2018.02.009

[5] S. Kweldju, "Using Geosemiotic Approach, Learners Create for Developing Multimodal Competencies: Task-Based," J-ELLiT (Journal English Lang. Lit. Teaching), vol. 3, no. 1, pp. 1-11, 2019. Available: http://journal2.um.ac.id/index.php/jellit/article/vie w/9899

[6] F. Tanrikulu, "Students' perceptions about the effects of collaborative digital storytelling on writing skills," Comput. Assist. Lang. Learn., pp. 116, 2020, DOI: 10.1080/09588221.2020.1774611

[7] Z. Lu , L. Hou, and X. Huang, "A research on a student-centred teaching model in an ICT-based English audio-video speaking class," International Journal of Education and Development using Information and Communication Technology (IJEDICT), vol. 6, no. 3, pp. 101-123, 2010.

[8] Y.F.D. Yang, "Multimodal Composing in Digital Storytelling," Comput. Compos., vol. 29, no. 3, pp. 221-238, 2012. 10.1016/j.compcom.2012.07.001

[9] M.D. Porto and I.A. Belmonte, "From local to global: Visual strategies of glocalisation in digital storytelling," Lang. Commun., vol. 39, pp. 14-23, 
2014. DOI: 10.1016/j.langcom.2014.05.001

[10] A.S. Urbieta and E.A. Peñalver, "Multimodal discourse in digital storytelling: An assessment tool proposal," Comp. Assisted Lang. Learning Elect. Journal, vol. 22, no. 2, pp. 14-25, 2021.

[11] D. Shin-Shin and T. Cimasko, "Multimodal Composition in a College ESL Class: New Tools, Traditional Norms," Computers and Composition, vol. 25, no. 4, pp. 376-395, 2008. DOI: 10.1016/j.compcom.2008.07.001

[12] S. Kweldju, "Educational Neuroscience for Second Language Classrooms," J-ELLiT (Journal English Lang. Lit. Teaching), vol. 3, no. 2, pp. 1-9, 2019. Available:

http://journal2.um.ac.id/index.php/jellit/article/vie w/11567

[13] A.L. Godhe and P. Magnusson, "Multimodality in language education - Exploring the boundaries of digital texts," in Conf. Proc. 25th Int. Conf. Comput. Educ, ICCE 2017. New Zealand, 2017, pp. 845854.

[14] C.C. Chao, "Creative language learning projects with emerging digital media," in 27th Pacific Asia Conf. Lang. Information, Comput, PACLIC 27. Taiwan, 2013, no. 64, pp. 512-519.

[15] C. Jewitt, "Multimodality and literacy in school classrooms," Review of Research Education, vol. 32, pp. 241-267, 2008. DOI: 10.3102/0091732X07310586

[16] G. Kress, Mutimodality A social semiotic approach to contemporary communication. Routledge, 2010.

[17] W.Y. Hwang, R. Shadiev, J.L. Hsu, Y.M. Huang, G.L. Hsu, and Y.C. Lin, "Effects of storytelling to facilitate EFL speaking using Web-based multimedia system," Comput. Assist. Lang. Learn., vol. 29, no. 2, pp. 215-241, 2016. DOI: 10.1080/09588221.2014.927367

[18] A. Tahriri, M.D. Tous, and S. Movahedfar, "The impact of digital storytelling on efl learners' oracy skills and motivation," Int. J. Appl. Linguist. English Lit., vol. 4, no. 3, pp. 144-153, 2015. Available: https://www.journals.aiac.org.au/index.php/IJALE L/article/view/1321 